2005, Journal for The Scientific Study of Religion, 44 (3), 349-359

\title{
The Effects of Childhood Maltreatment on Adult Religiosity and Spirituality: Rejecting God the Father Because of Abusive Fathers?
}

\author{
ALEX BIERMAN
}

\begin{abstract}
Current theories can support conflicting accounts of the effects of childhood maltreatment on adult religiosity. However, in the relevant empirical research there are few examples of probability sampling or a focus on nonsexual forms of abuse. It is also uncommon to control for risk factors for abuse, which may themselves also affect adult religiosity. This study attempts to overcome some of these limitations by examining the effects of physical and emotional abuse on adult religiosity and spirituality in a U.S. probability sample of adults at midlife. Neither maltreatment from mothers nor from outside the family has an effect on religiosity, but abuse committed by fathers is related to decreases in religiosity, and abuse from outside the immediate family is related to increases in selfratings of spirituality. Possible explanation for these results may be related to the image of God as father, which leads victims of abusive fathers to distance themselves from religion.
\end{abstract}

\section{INTRODUCTION}

In this study, I examine whether and how experiences of physical and emotional maltreatment in childhood are related to religiosity and spirituality in adulthood. Within the literature, arguments can be found that support two different views of this relationship. Some argue that people who experience trauma such as maltreatment in childhood may question how a benevolent God could allow this maltreatment to occur, and therefore turn away from the worship of God or deny the existence of a divine creator altogether (Russell 1986; Wilson and Moran 1998).

Alternatively, some authors agree that childhood maltreatment is generally traumatic, but claim that this trauma may in fact have important consequences for spiritual growth (Decker 1993; Garbarino and Bedard 1996). Infliction of horrible deeds on one's body or mind may undermine or violate beliefs that there is a meaningful order to the universe (Herman 1992; Janoff-Bulman and Thomas 1989). This may paradoxically lead to an increase in one's spirituality, as the attempt to reestablish a sense of meaning "propels a person to a higher stage of spiritual development" (Ryan 1998a:47; see also Tedeschi and Calhoun 2004). It is possible that religion may play an important role in this spiritual development, and people may even seek out or strengthen religious beliefs or behavior as a way of rebuilding a sense of meaningful order, thus increasing victims' religiosity.

Currently, most of the empirical research falls on the side of the more pessimistic view of the effects of childhood maltreatment on adult religiosity. Most research has shown that victims of abuse tend to have more negative views of God, are less likely to believe in God, and are less likely to be involved in organized religion or not practice a religion (Finkelhor et al. 1989; Hall 1995; Kane, Cheston, and Greer 1993; Kennedy and Drebing 2002; Lawson et al. 1998; Pritt 1998; Russell 1986).

However, several of these studies have weaknesses that lead to uncertainty regarding how well they establish the relationship between maltreatment and adult religiosity. Many are based on convenience sampling of fairly specialized groups, such as male veterans undergoing substance

Correspondence should be addressed to Alex Bierman, Department of Sociology, University of Maryland, 2112 ArtSociology Bldg., College Park, MD 20742.E-mail: abierman@socy.umd.edu 
abuse treatment or women who attend Christian counseling agencies and churches (Hall 1995; Lawson et al. 1998). More importantly, most research has not controlled for background factors that predispose individuals to the risk of abuse and have also been shown to be related to religiosity, such as minority racial status and family socioeconomic status (Beit-Hallahmi and Argyle 1997; Black, Slep, and Heyman 2001; Lee and Goerge 1999; Sedlak 1997). Furthermore, child maltreatment often emerges from families that are relatively dysfunctional or unstable (Briere 1992; Langeland and Hartgers 1998; Zuravin and Fontanella 1999), and a failure to control for this characteristic leads to the question of whether it is the trauma of family instability or abuse that accounts for the effects of abuse on adult religiosity.

Research has also generally tended to concentrate on female victims of child sexual abuse, leaving open the question of whether other types of abuse have the same effects on religiosity. This is especially important to consider since children are more likely to be emotionally or physically abused than sexually abused (Sedlak 1997; Sedlak and Broadhurst 1996). This also means that there has been little consideration of the moderating effects of gender on the relationship between child maltreatment and adult religiosity. Gender may in fact be critical because one of the most basic findings in the sociology of religion is that that women tend to be more religious than men on most measures of religiosity (Miller and Hoffmann 1995; Stark 2002; Walter and Davie 1998). This may mean that maltreatment is more likely to affect women's religiosity than men's, but this may also mean that there are greater normative pressures for women to maintain their religiosity, so that maltreatment has a stronger effect on men's religiosity. Furthermore, even if gender does not act as a moderator for this relationship, research has also shown that boys are more likely to experience nonsexual forms of maltreatment than girls (Lee and Goerge 1999), so it is critical to control for gender as an additional background factor that may affect both risk of abuse and adult religiosity.

In addition, there has been little focus on the source of the maltreatment. This may be important if the perpetrator is a parent, because the relationship between individuals and God is similar to that of parent and child (Kirkpatrick 1992), and in fact is often couched in this terminology (Kaufman 1981; Lemoncelli and Carey 1996). As a result, people may come to associate God with this victimizing behavior (Manlowe 1995), so that maltreatment committed by a parent may have greater negative effects on adult religiosity than abuse committed by others. However, it may also be the case that these effects are specific to abuse perpetrated by fathers, because in Judeo-Christian traditions God is often described specifically as a father (Freud 1965). Therefore, it may be abusive fathers specifically who cause victims to see a higher power as a capricious, uncaring being (Kane et al. 1993; Saussy 1991), resulting in a decrease in religiosity.

There is also some research that supports a more positive view of the relationship between child maltreatment and adult religiosity. Although not focusing specifically on abuse, several studies have shown that individuals experiencing stressful events may turn to religion as a means of coping with these experiences (for reviews, see Harrison et al. 2001; Pargament 1997). Conceivably, then, victims of childhood abuse may turn to religion to cope with the stress of abuse, and these coping efforts may follow them into adulthood in the form of increased religiosity. While the research on abuse and adult religiosity cited above does not support this view, it is also possible that the methodological limitations of previous research obscured this positive relationship.

Finally, a distinction may be made between the effects of maltreatment on religiosity and those on spirituality. For instance, Ryan (1998a:47) notes in a literature review that child maltreatment may result in victims "turning to a more personal form of spiritual practice." While the distinction between religiosity and spirituality may not be precise, for victims this appears to be in part an attempt to separate themselves from formal religious practices and beliefs, while still maintaining a sense of the mystical or preternatural in their lives. Or, as one survivor of childhood sexual abuse said: "Spirituality is more important to me now than religion" 
(quoted in Kane et al. 1993:235). This suggests that, in addition to considering religiosity, research should also consider the relationship between child maltreatment and victims' sense of their own spirituality. It is possible that victims' attempts to reestablish a sense of meaning may lead them to see themselves as being more spiritual, even if maltreatment leads them to be less religious. This is supported by research that found that female victims of sexual and emotional abuse had higher scores on a "spiritual experiences" scale (Reinert and Smith 1997). Similarly, Ryan (1998b) indicated that some victims of abuse turn away from religion, but many victims in her study considered their abusive experiences to be catalysts for an increased sense of spirituality.

In conclusion, while there is a degree of empirical research that supports both views regarding the effects of child maltreatment on adult religiosity, the methodological limitations of some of this research leave the conflict far from resolved. My intention is to overcome some of these limitations by using data gathered through probability sampling methods, while controlling for a number of factors that are related to risk of abuse and adult religiosity. In addition, I also explore whether the relationship of the perpetrator to the victim, as well as the gender of the victim, affect the relationship between child maltreatment and adult religiosity and spirituality.

\section{Data and Measures}

\section{Data}

This study uses data from the National Survey of Midlife Development in the United States (MIDUS) (Brim et al. 1996). The MIDUS is a large $(N=3,032)$ national survey, which was conducted in 1995 of noninstitutionalized, English-speaking adults aged 25-74 years living in the coterminous United States.

Data for the MIDUS were gathered at two separate times. Respondents were initially contacted by telephone through random-digit dialing and were asked a short series of questions in an interview that lasted an average of 30 minutes. Within a week of the telephone stage of the survey, subjects were mailed a longer and more detailed questionnaire that took an average of two hours to complete. All respondents were given $\$ 20$ with the mailed questionnaire, as well as a boxed pen. Furthermore, one-fourth of households were randomly designated during the telephone stage of sampling for an additional financial incentive $(\$ 100)$ if they refused the telephone or mail survey. It is estimated that the response rate for the MIDUS was 70 percent for the telephone interview, 86.8 percent for the completion of the main questionnaire among the telephone respondents, and 60.8 percent for the overall response rate. Analyses are weighted to correct for biases in the sample. ${ }^{1}$

\section{Measures}

\section{Dependent Variables}

\section{Religious Involvement}

Two questions were used to measure the degree to which respondents were involved in religious organizations or groups. Respondents were asked to indicate the number of times "in a typical month" they attended "religious services," and then, in a second question, the number of times they attended "meetings of religious groups." Responses to the two questions are summed to provide an overall indication of typical involvement in organizational religious activities. Because more than 95 percent of respondents indicated scores of 13 or less, with an extremely large range 
for the few remaining respondents, the top value for the measure used in the analysis is 13 or more.

\section{Religious Self-Concept}

A measure of religious involvement does not, however, measure the degree to which the individual perceives himself or herself as religious. Even if experiences of abuse do not affect the frequency with which people are involved in religious groups or organizations, if religious beliefs help victims cope with the trauma of abuse or provide resolution to a crisis of meaning caused by experiences of maltreatment, victims of abuse may nevertheless see themselves as more religious. Religious self-concept was measured by an index consisting of two items, one of which asked, "How religious are you?" and a second, which asked "How important is religion in your life?" All items were measured on a scale of 1 (very) to 4 (not at all), with responses reverse coded so that larger numbers indicated a greater sense of religiousness. Alpha coefficient for the index was 0.88 .

\section{Spiritual Self-Concept}

Although a specific measure of spiritual beliefs or spiritual involvement was not included in the MIDUS, a measure of spiritual self-concept was included. This provided a way to investigate whether child maltreatment has different effects on the degree to which individuals perceive themselves as religious and the degree to which they perceive themselves as spiritual. This measure was composed of two items, "How spiritual are you?" and "How important is spirituality in your life?" All items were measured on a scale of 1 (very) to 4 (not at all), with responses reverse coded so that larger numbers indicated a greater sense of spirituality. Alpha coefficient for the index was 0.89 .

\section{Independent Variables}

\section{Physical and Emotional Abuse}

Questions measuring abuse were taken from a commonly used measure, the Conflict Tactics Scale (CTS) (Straus and Gelles 1990). The CTS asks about the frequency of a variety of interactions between children and parents but, presumably due to the length of the MIDUS, the CTS was condensed. Respondents were presented with a list of emotionally abusive behaviors, including: "Insulted you or swore at you; sulked or refused to talk to you; stomped out of the room; did or said something to spite you; threatened to hit you; and smashed or kicked something in anger." Respondents were then asked, "During your childhood, how often did your mother, or the woman who raised you do any of the things" on the list "to you," with responses ranging from 1 (often) to 4 (never). ${ }^{2}$ The same question was then asked again, but this time in reference to "your father, or the man who raised you," and a third question was asked in reference to abuse from outside the immediate family. The reference to people who raised the child is useful because it allows the respondent to describe individuals who were not biological parents, but still acted in the role of father or mother.

Severe physical abuse was measured using similar questions, but this time the list of behaviors included "kicked, bit, or hit you with a fist; hit or tried to hit you with something; beat you up; choked you; burned or scalded you." In the analysis, all abuse items were reverse coded, so that higher values indicated greater frequency of abuse. Responses to questions about each source of abuse were summed to form separate measures of frequency of physical and emotional abuse from fathers, from mothers, and from outside the immediate family. ${ }^{3}$ Alpha coefficients for the three abuse indexes ranged between 0.62 and 0.65 . 


\section{Gender}

Gender was a dichotomous variable with men coded as the higher value.

\section{Race}

Race was measured with one item, which asked, "What race do you consider yourself to be?" Respondents were then given a list of racial categories, including "White; Black and/or African American; Native American or Aleutian Islander/Eskimo; Asian or Pacific Islander; Other; or Multiracial" and asked to choose only one option. In this analysis, responses were coded as a series of dummy variables, with "White" as the reference category. Due to the number of respondents in each category, responses of Native American, Asian, Other, and Multiracial were combined into an "Other/Multiracial" category.

\section{Family Background}

Two measures of family background were used. One was a measure of family poverty that was used as an indicator of socioeconomic status during childhood. This measure asked, "During your childhood and adolescence, was there ever a period of six months or more when your family was on welfare or ADC [Aid to Families with Dependent Children]?" A second item examined family stability by asking if the respondent lived with both biological parents until he or she was 16 years of age. Responses to both items were dichotomous, with an affirmative response coded as the higher value.

\section{Control Variables}

In all the multivariate analyses, several variables related to religiosity were included as control variables. These include education, income, marital status, and age. Marital status was measured with a dichotomous married/nonmarried variable. Education was measured on a scale of 1 (no school/some grade school (1-6)) to 12 (Ph.D., Ed.D., M.D., D.D.S., L.L.B., L.L.D., J.D., or other professional degree). Respondents were asked to indicate their income using a scale of 39 categories of income, from less than $\$ 0$ (loss) to $\$ 1,000,000$ or more. Respondents were asked about six different types of income: personal earnings, spouse's or partner's personal earnings, other family members' earnings, Social Security retirement benefits, government assistance, and other family income. Responses for each question were assigned the midpoint for the income category, and the responses for the six items were summed. Several people did not respond to one or more of the six income questions, though, and, for these cases, on five of the six questions income was imputed by using the mean income for the respondent's level of education. The only exception to this was for the item on Social Security income, for which mean income for age rather than level of education was used. Furthermore, to avoid outliers unduly influencing data analyses, all respondents whose combined income was at or above the 95th percentile $(\$ 185,000)$ were reclassified as having $\$ 185,000$ in income. To provide a more clear demonstration of the effect of income, this measure was adjusted to units of tens of thousands.

\section{RESULTS}

\section{Bivariate Relationships}

Means, standard deviations, and zero-order correlations are presented in Table 1. Several relationships are of interest. First, abuse from each source is significantly and negatively correlated with both measures of religiosity. Second, there are moderate correlations among the different 


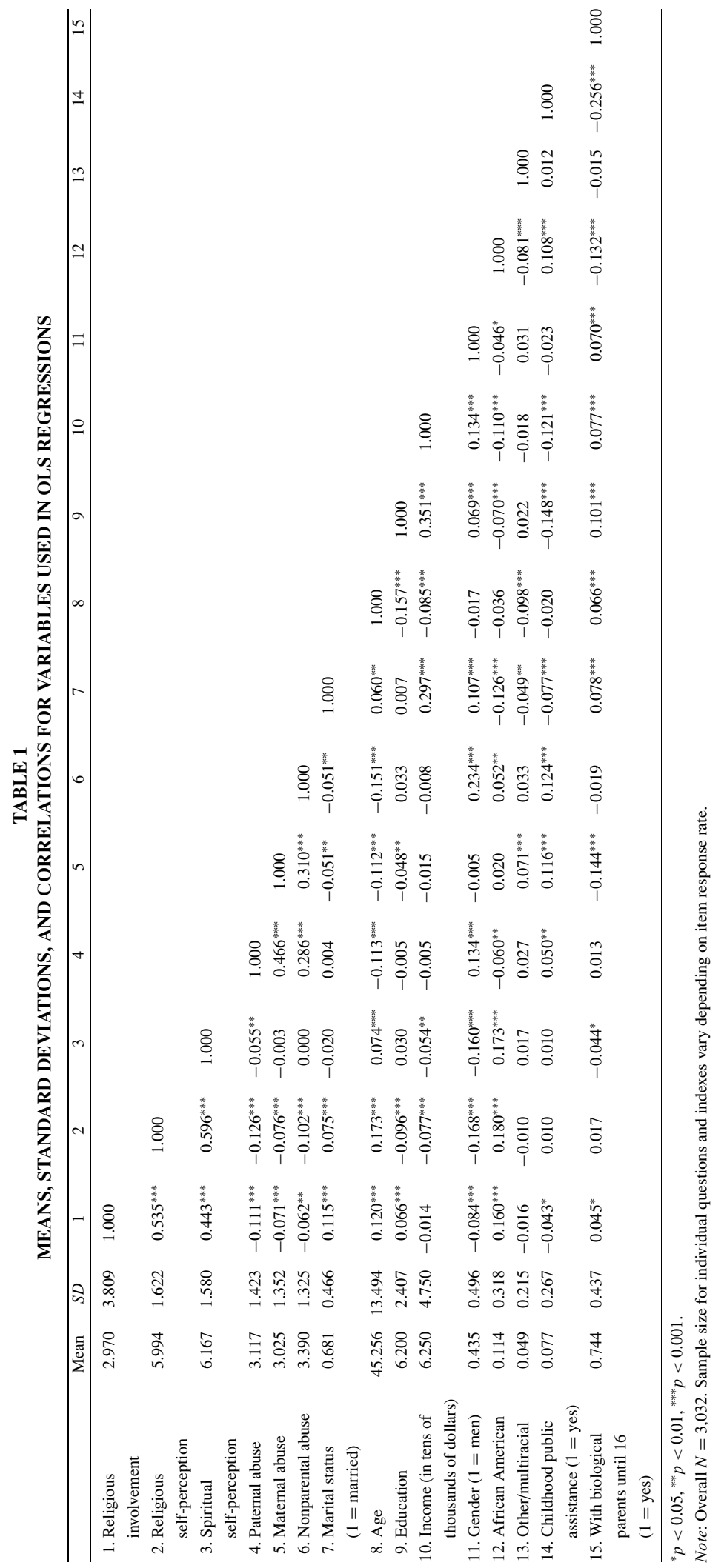


sources of abuse. This indicates that, despite the bivariate results, it is important to consider the independent effects of these different sources of abuse. ${ }^{4}$ In addition, race, gender, and family background are all related to at least one measure of maltreatment and religiosity or spirituality, which demonstrates a need to take these factors into account when considering the effects of nonsexual forms of maltreatment on religiosity and spirituality.

There is also a fairly strong correlation between the two self-concept scales. This raises a concern as to whether these scales actually measure different dimensions of religiosity and spirituality. To find whether this is the case, a confirmatory factor analysis was performed on the self-concept items. Two models were compared: one in which separate but correlated factors underlay each set of items, and one in which one factor underlay all four items. The results of this analysis showed that the two-factor solution fit the data significantly better $\left(\chi^{2}\right.$ difference was $1,662.179(1 d f), p<0.001) .{ }^{5}$ Hence, although related, it appears that the two self-concept indexes do measure separate dimensions.

\section{The Effects of Maltreatment on Religiosity and Spirituality}

The results of the OLS regression analyses are shown in Table 2. Two regressions are presented for each dependent variable. The first examines the independent effects of each source of maltreatment, along with the control variables, while the second examines the extent to which these relationships are due to background factors associated with risk of abuse. These results demonstrate that it is paternal abuse that has the primary negative association with religiosity. Paternal abuse has a significant negative effect on religious involvement in Model 1, and this effect remains highly significant ( $p<0.001$ ), even after controlling for gender, race, and family background factors. Furthermore, paternal abuse also has a significant negative association with religious self-concept, and this association also retains its significance $(p<0.001)$ in Model 2. In no model is maternal abuse significantly related to either measure of religiosity. While nonparental abuse is not related to religious involvement, in the first model for religious self-concept, nonparental abuse has a significant negative association, but this association is reduced to nonsignificance with the inclusion of gender, race, and family background. This clearly illustrates the need to take these background factors into account when analyzing the relationship between child maltreatment and adult religiosity.

Spirituality reveals a somewhat different story. In the first model, of the abuse variables, only paternal abuse is significantly related to spiritual self-concept $(p<0.001)$, and this relationship is negative. However, with the inclusion of background variables in Model 2, this relationship is reduced to nonsignificance, while the relationship between nonparental abuse is significant $(p<$ 0.05 ) and positive. Therefore, not only do the characteristics associated with risk of abuse appear to explain the relationship between paternal abuse and spiritual self-concept, there appears to be a suppression effect for the association between spiritual self-concept and nonparental abuse. Hence, it is also important to take these background factors into account when considering the relationship between maltreatment and spirituality.

\section{Gender Differences in the Effects of Maltreatment}

Interactions between maltreatment and gender were tested twice-once separately and a second time in the same model. ${ }^{6}$ As a third test, regressions were run separately for men and women, and $z$-scores for differences in beta coefficients were calculated (Cohen 1983). Under no circumstances were the effects of maltreatment found to be significantly different for men and women, even using the relatively liberal standard of $p<0.10$. The results of this analysis do not support the contention that the effects of maltreatment on religiosity and spirituality differ significantly between men and women. 
TABLE 2

OLS REGRESSIONS EXAMINING THE EFFECTS OF PHYSICAL AND EMOTIONAL CHILD MALTREATMENT ON ADULT RELIGIOSITY AND SPIRITUALITY

\begin{tabular}{|c|c|c|c|c|c|c|}
\hline & \multicolumn{2}{|c|}{ Religious Involvement } & \multicolumn{2}{|c|}{ Religious Self-Concept } & \multicolumn{2}{|c|}{ Spiritual Self-Concept } \\
\hline & Model 1 & Model 2 & Model 1 & Model 2 & Model 1 & Model 2 \\
\hline Paternal abuse & $\begin{array}{l}-0.279^{* * *} \\
(-0.105)\end{array}$ & $\begin{array}{l}-0.225^{\text {*** }} \\
(-0.085)\end{array}$ & $\begin{array}{l}-0.123^{* * *} \\
(-0.108)\end{array}$ & $\begin{array}{l}-0.089^{* * *} \\
(-0.079)\end{array}$ & $\begin{array}{l}-0.085^{* * *} \\
(-0.076)\end{array}$ & $\begin{array}{l}-0.044 \\
(-0.04)\end{array}$ \\
\hline Maternal abuse & $\begin{array}{c}0.040 \\
(0.014)\end{array}$ & $\begin{array}{c}0.016 \\
(0.006)\end{array}$ & $\begin{array}{l}0.008 \\
(0.006)\end{array}$ & $\begin{array}{l}-0.020 \\
(-0.016)\end{array}$ & $\begin{array}{c}0.039 \\
(0.034)\end{array}$ & $\begin{array}{l}-0.001 \\
(-0.001)\end{array}$ \\
\hline Nonparental abuse & $\begin{array}{l}-0.045 \\
(-0.016)\end{array}$ & $\begin{array}{c}0.006 \\
(0.002)\end{array}$ & $\begin{array}{c}-0.059^{*} \\
(-0.048)\end{array}$ & $\begin{array}{c}-0.022 \\
(-0.018)\end{array}$ & $\begin{array}{c}0.015 \\
(0.013)\end{array}$ & $\begin{array}{c}0.061^{*} \\
(0.051)\end{array}$ \\
\hline $\begin{array}{l}\text { Marital status } \\
\qquad(1=\text { married })\end{array}$ & $\begin{array}{l}1.136^{* * *} \\
(0.14)\end{array}$ & $\begin{array}{l}1.311^{\text {*** }} \\
(0.162)\end{array}$ & $\begin{array}{l}0.314^{* * *} \\
(0.09)\end{array}$ & $\begin{array}{l}0.418^{* * *} \\
(0.12)\end{array}$ & $\begin{array}{l}-0.018 \\
(-0.005)\end{array}$ & $\begin{array}{c}0.092 \\
(0.027)\end{array}$ \\
\hline Age & $\begin{array}{l}0.030^{* * *} \\
(0.105)\end{array}$ & $\begin{array}{l}0.033^{* * *} \\
(0.116)\end{array}$ & $\begin{array}{l}0.016^{* * *} \\
(0.127)\end{array}$ & $\begin{array}{l}0.018^{* * *} \\
(0.144)\end{array}$ & $\begin{array}{l}0.007^{* *} \\
(0.062)\end{array}$ & $\begin{array}{l}0.010^{* * *} \\
(0.083)\end{array}$ \\
\hline Education & $\begin{array}{l}0.195^{* * *} \\
(0.124)\end{array}$ & $\begin{array}{l}0.193^{* * *} \\
(0.123)\end{array}$ & $\begin{array}{l}-0.027^{*} \\
(-0.04)\end{array}$ & $\begin{array}{c}-0.023 \\
(-0.035)\end{array}$ & $\begin{array}{l}0.048^{* * *} \\
(0.073)\end{array}$ & $\begin{array}{l}0.053^{* * *} \\
(0.081)\end{array}$ \\
\hline $\begin{array}{l}\text { Income in tens } \\
\text { of thousands } \\
\text { of dollars }\end{array}$ & $\begin{array}{l}-0.078^{* * *} \\
(-0.098)\end{array}$ & $\begin{array}{l}-0.066^{* * *} \\
(-0.082)\end{array}$ & $\begin{array}{l}-0.027^{* * *} \\
(-0.079)\end{array}$ & $\begin{array}{l}-0.019^{* *} \\
(-0.057)\end{array}$ & $\begin{array}{l}-0.022^{* *} \\
(-0.067)\end{array}$ & $\begin{array}{c}-0.014^{*} \\
(-0.043)\end{array}$ \\
\hline Gender $(1=$ male $)$ & & $\begin{array}{l}-0.700^{* * *} \\
(-0.092)\end{array}$ & & $\begin{array}{l}-0.491^{\text {*** }} \\
(-0.151)\end{array}$ & & $\begin{array}{l}-0.516^{* * *} \\
(-0.162)\end{array}$ \\
\hline African American ${ }^{\mathrm{a}}$ & & $\begin{array}{l}1.979^{* * *} \\
(0.158)\end{array}$ & & $\begin{array}{l}0.901^{* * *} \\
(0.168)\end{array}$ & & $\begin{array}{l}0.790^{* * *} \\
(0.151)\end{array}$ \\
\hline Other/multiracial $^{\mathrm{a}}$ & & $\begin{array}{c}0.396 \\
(0.022)\end{array}$ & & $\begin{array}{c}0.269 \\
(0.035)\end{array}$ & & $\begin{array}{l}0.330^{*} \\
(0.045)\end{array}$ \\
\hline $\begin{array}{l}\text { Childhood public } \\
\text { assistance }\end{array}$ & & $\begin{array}{l}-0.323 \\
(-0.023)\end{array}$ & & $\begin{array}{c}0.053 \\
(0.009)\end{array}$ & & $\begin{array}{l}-0.057 \\
(-0.01)\end{array}$ \\
\hline $\begin{array}{c}(1=\text { yes }) \\
\text { With biological } \\
\text { parents until } \\
16(1=\text { yes })\end{array}$ & & $\begin{array}{l}0.459^{* *} \\
(0.053)\end{array}$ & & $\begin{array}{r}0.167^{*} \\
(0.045)\end{array}$ & & $\begin{array}{l}-0.080 \\
(-0.022)\end{array}$ \\
\hline Constant & 0.970 & 0.149 & 5.950 & 5.551 & 5.753 & 5.515 \\
\hline Adjusted $R^{2}$ & 0.049 & 0.081 & 0.052 & 0.099 & 0.012 & 0.058 \\
\hline
\end{tabular}

${ }^{a}$ White is reference group.

${ }^{*} p<0.05,{ }^{* *} p<0.01,{ }^{* * *} p<0.001$.

Note: Unstandardized coefficients; standardized coefficients in parentheses. Weighted $N$ varies between 2,688 and 2,732, depending on the response rate for the dependent variable.

\section{Discussion}

This article examined the degree to which experiences of nonsexual forms of child maltreatment affect adult religiosity and spirituality. While previous research has shown a negative association between maltreatment and adult religiosity, methodological concerns leave some question as to whether there is a relationship and, if so, the direction of the relationship. While this study did find a negative relationship between maltreatment and religiosity, it also indicated that the source of the maltreatment is crucial for the effects of physical and emotional maltreatment 
on religiosity. In these results, once controls for risk factors for abuse were included in regression models, only maltreatment perpetrated by fathers had a significant negative effect on religiosity.

The most obvious explanation for this pattern of results involves the identification of God as a paternal figure. Individuals who are brought up with harsh, capricious fathers may well form a negative view of paternal figures. In many Western religions, a higher power is depicted in paternal imagery. The negative view of paternal figures that victims of paternal abuse may form from their experiences could lead them to distance themselves from these celestial paternal figures, leading to a decrease in religious activities and self-perceived religiosity. The current research could not, however, firmly establish the paternal identification of a higher power as the mechanism for these results. Future research should more closely examine the question of whether victims of physical and emotional abuse are lower in religious involvement and self-perceived religiosity because they identify God with abusive fathers.

It should also be noted that this research does not address specific religious traditions, as there were no measures of childhood religious affiliation, or parents' religious affiliation during childhood, in the data. Attention to religious traditions may be important for future research, though, because previous research has shown that conservative religious beliefs tend to lead individuals to value "obedience" in children more strongly (Ellison and Sherkat 1993); similarly, conservative Protestants are more likely to employ corporal punishment, and theological conservatism has been shown to explain these differences (Ellison, Bartkowski, and Segal 1996). If parents employ these religious beliefs as justifications for the maltreatment of children, this could leave the religiosity of adults who were raised in some faiths to be more strongly affected by child maltreatment than adults who were raised in other faiths or no faiths. In the future, then, it would be advisable to study whether the effects of child maltreatment on adult religiosity differ by religious upbringing.

My findings also show positive effects of child maltreatment on spirituality. Maltreatment from outside the immediate family was positively related to spiritual self-perceptions. Why only maltreatment from outside the immediate family should be related to spirituality is not clear. This may indicate that, even if victims of abuse see themselves as more spiritual than religious, in many cases they may not differ from other individuals in terms of their self-perceived spirituality. However, it is also important to remember that only self-perceptions were examined in this research. Use of a wider number of measures of spirituality, especially of behaviors or beliefs, which many would see as "spiritual," but not necessarily "religious," may help to clarify these results. For instance, had belief in astrology or the practice of transcendental mediation been examined, maternal or paternal abuse might have had a significant relationship with these measures as well.

Surprisingly, while religiosity may differ substantially between men and women, the victim's gender did little to moderate the effects of child maltreatment on religiosity or spirituality. Background characteristics were still important, though, as controlling for a variety of background factors reduced to nonsignificance more than one relationship with maltreatment. Therefore, research that does not take the characteristics related to risk of abuse, and to adult religiosity and spirituality, into account may greatly misestimate the effects of maltreatment on religiosity and spirituality.

Furthermore, people in this study may have experienced maltreatment decades before the survey was administered, so it is possible that people may turn to religion to cope with abuse during childhood or adolescence, but these effects do not persist throughout adulthood. In addition, the MIDUS data used in this research were specifically of adults at midlife. It is possible that, as individuals come closer to the end of life, they may be more likely to turn to religion or reconcile their early traumatic experiences, leading to a diminishment of the negative effects of child maltreatment on adult religiosity.

In closing, this study represents the first time that a national probability sample has been used to examine the effects of physical and emotional forms of child maltreatment on adult religiosity and spirituality. This has been a relatively understudied topic, but there do appear to be effects 
of physical and emotional child maltreatment on adult religiosity and spirituality. Clearly, the reasons for these effects deserve far more attention in the future.

\section{ACKNOWLedgments}

I wish to thank Larry Hunt for insightful comments and valuable suggestions on an earlier draft of this article. I also thank the editor and anonymous reviewers for their suggestions, as well as Melissa Milkie for encouraging the early stages of this research. A version of this article was presented at the 2004 meetings of the American Sociological Association, San Francisco, CA.

\section{Notes}

1. For more information on the MIDUS, including the weights used in this study, see the homepage for the MIDUS at http://midmac.med.harvard.edu/.

2. For the parental abuse questions, there was also an option of checking "does not apply." Responses of "does not apply" were coded along with responses of "never," under the reasoning that people for whom this question was inapplicable did not experience this form of abuse.

3. Combination of these measures may raise some concern that different forms of abuse are being confounded, but factor analyses of different types of child abuse by Bolger and Patterson (2001) found that physical and emotional abuse load on the same factor. Brezina (1998) also found similar results in a factor analysis of measures of physical and emotional maltreatment experienced in adolescence. This indicates that it is appropriate to combine measures of physical and emotional abuse into indexes of nonsexual abusive experiences.

4. The association between independent variables also leads to concerns of multicollinearity, but all variance inflation factors (VIFs) were below 1.5 in the main effects models, indicating that multicollinearity did not substantially bias results.

5. The two-factor model had a $\chi^{2}$ statistic of $587.87(1 d f)$; comparative fit index (CFI) and normed fit index (NFI) for the model were 0.93, while RMSEA was 0.45 (90 percent CI: 0.42, 0.48) and SRMR was 0.04. With Satorra-Bentler (1994) corrections for nonnormality, CFI and NFI for the model were 0.95 and RMSEA was 0.27 (90 percent CI: 0.24, 0.30). Recommendations for fit indexes is that the NFI and CFI should be at least 0.95 , less than 0.05 for the RMSEA, and 0.05 or less for the SRMR (Byrne 2001). Overall, then, the model fit seems to be marginally acceptable, but the important point is that the better representation of the data is that they comprise two indexes, rather than one.

6. To avoid multicollinearity, all abuse variables were centered over their respective means prior to the creation of interaction terms (Aiken and West 1991).

\section{REFERENCES}

Beit-Hallahmi, B. and M. Argyle. 1997. The psychology of religious behaviour, belief \& experience. London: Routledge.

Black, D. A., A. M. S. Slep, and R. E. Heyman. 2001. Risk factors for psychological abuse. Aggression and Violent Behavior 6:189-201.

Bolger, K. E. and C. J. Patterson. 2001. Developmental pathways from child maltreatment to peer rejection. Child Development 72:549-68.

Brezina, T. 1998. Adolescent maltreatment and delinquency: The question of intervening processes. Journal of Research in Crime and Delinquency 35:71-99.

Briere, J. 1992. Methodological issues in the study of sexual abuse effects. Journal of Consulting and Clinical Psychology 60:196-203.

Brim, O. G., P. B. Baltes, L. L. Bumpass, C. D. Ryff, P. D. Cleary, R. C. Kessler, D. L. Featherman, W. R. Hazzard, M. E. Lachman, H. R. Markus, M. G. Marmot, A. S. Rossi, and R. A. Shweder. 1996. National survey of midlife development in the United States (MIDUS), 1995-1996 [MRDF]. Cambridge, MA: Harvard Medical School, Dept. of Health Care Policy [producer]. Ann Arbor, MI: Inter-University Consortium [distributor].

Byrne, B. M. Structural equation modeling with AMOS: Basic concepts, applications, and programming. Mahwah, NJ: Lawrence Erlbaum Associates.

Cohen, A. 1983. Comparing regression coefficients across subsamples: A study of the statistical test. Sociological Methods and Research 12:77-94.

Decker, L. R. 1993. The role of trauma in spiritual development. Journal of Humanistic Psychology 33:33-46.

Ellison, C. G., J. P. Bartkowski, and M. L. Segal. 1996. Conservative Protestantism and the parental use of corporal punishment. Social Forces 74:1003-28.

Ellison, C. G. and D. E. Sherkat. 1993. Obedience and autonomy: Religion and parental childrearing values reconsidered. Journal for the Scientific Study of Religion 32:313-29. 
Finkelhor, D., G. T. Hotaling, I. A. Lewis, and C. Smith. 1989. Sexual abuse and its relationship to later sexual satisfaction, marital status, religion, and attitudes. Journal of Interpersonal Violence 4:379-99.

Freud, S. 1965. New introductory lectures on psychoanalysis. New York: WW Norton \& Company Inc.

Garbarino, J. and C. Bedard. 1996. Spiritual challenges to children facing violent trauma. Childhood 3:467-78.

Hall, T. A. 1995. Spiritual effects of childhood sexual abuse in adult Christian women. Journal of Psychology and Theology 23:129-34.

Harrison, M. O., H. G. Koenig, J. C. Hays, A. G. Eme-Akwari, and K. I. Pargament. 2001. The epidemiology of religious coping: A review of recent literature. International Review of Psychiatry 13:86-93.

Herman, J. L. 1992. Trauma and recovery. New York: Basic Books.

Janoff-Bulman, R. and C. E. Thomas. 1989. Toward an understanding of self-defeating responses following victimization. In Self-defeating behaviors: Experimental research, clinical impressions, and practical implications, edited by R. C. Curtis, pp. 215-34. New York: Plenum Press.

Kane, D., S. E. Cheston, and J. Greer. 1993. Perceptions of God by survivors of childhood sexual abuse: An exploratory study in an underresearched area. Journal of Psychology and Theology 21:228-37.

Kaufman, G. D. 1981. The theological imagination: Constructing the concept of God. Philadelphia, PA: Westminster.

Kennedy, P. and C. E. Drebing. 2002. Abuse and religious experience: A study of religiously committed evangelical adults. Mental Health, Religion and Culture 5:225-37.

Kirkpatrick, L. A. 1992. An attachment-theory approach to the psychology of religion. International Journal for the Psychology of Religion 2:3-28.

Langeland, W. and C. Hartgers. 1998. Child sexual and physical abuse and alcoholism: A review. Journal of Studies on Alcohol 59:336-48.

Lawson, R., C. Drebing, G. Berg, A. Vincellette, and W. Penk. 1998. The long-term impact of child abuse on religious behavior and spirituality in men. Child Abuse and Neglect 22:369-80.

Lee, B. J. and R. M. Goerge. 1999. Poverty, early childbearing, and child maltreatment: A multinomial analysis. Children and Youth Services Review 21:755-80.

Lemoncelli, J. and A. Carey. 1996. The psychospiritual dynamics of adult survivors of abuse. Counseling and Values 40:175-84.

Manlowe, J. L. 1995. Faith born of seduction. New York: New York University Press.

Miller, A. S. and J. P. Hoffmann. 1995. Risk and religion: An explanation of gender differences in religiosity. Journal for the Scientific Study of Religion 34:63-75.

Pritt, A. F. 1998. Spiritual correlates of reported sexual abuse among Mormon women. Journal for the Scientific Study of Religion 37:237-85.

Reinert, D. F. and C. E. Smith. 1997. Childhood sexual abuse and female spiritual development. Counseling and Values 41:235-45.

Ryan, P. L. 1998a. Spirituality among adult survivors of childhood violence: A literature review. Journal of Transpersonal Psychology 30:39-51.

- 1998b. An exploration of the spirituality of fifty women who survived childhood violence. Journal of Transpersonal Psychology 30:87-102.

Pargament, K. I. 1997. The psychology of religion and coping: Theory, research, practice. New York: Guilford Press.

Russell, D. E. H. 1986. The secret trauma: Incest in the lives of girls and women. New York: Basic Books.

Satorra, A. and P. M. Bentler. 1994. Corrections to standard errors in covariance structure analysis. In Latent variable analysis: Applications to developmental research, edited by A. von Eye and C. C. Clogg, pp. 399-419. Thousand Oaks, CA: Sage.

Saussy, C. 1991. God images and self esteem: Empowering women in a patriarchal society. Louisville, KY: Westminster/John Knox Press.

Sedlak, A. J. 1997. Child physical maltreatment and exposure to violence in families: Issues, interventions, and research: Risk factors for the occurrence of child abuse and neglect. Journal of Aggression, Maltreatment, and Trauma 1:149-87.

Sedlak, A. J. and D. D. Broadhurst. 1996. Executive summary of the Third National Incidence Study of Child Abuse and Neglect (NIS-3). Washington, DC: U.S. Department of Health and Human Services, Administration for Children and Families, Administration on Children, Youth and Families, and National Center on Child Abuse and Neglect.

Stark, R. 2002. Physiology and faith: Addressing the "universal" gender difference in religious commitment. Journal for the Scientific Study of Religion 41:495-507.

Straus, M. A. and R. J. Gelles. 1990. Physical violence in American families: Risk factors and adaptations to violence in 8,145 families. New Brunswick, NJ: Transaction Publishers.

Tedeschi, R. G. and L. G. Calhoun. 2004. Posttraumatic growth: Conceptual foundations and empirical evidence. Psychological Inquiry 15:1-18.

Walter, T. and G. Davie. 1998. The religiosity of women in the modern West. British Journal of Sociology 49:640-59.

Wilson, J. P. and T. A. Moran. 1998. Psychological trauma: Posttraumatic stress disorder and spirituality. Journal of Psychology and Theology 26:168-78.

Zuravin, S. J. and C. Fontanella. 1999. The relationship between child sexual abuse and major depression among lowincome women: A function of growing up experiences? Child Maltreatment 4:3-12 